\title{
Sustainability and Economic Performance: Role of Organizational Learning and Innovation
}

\author{
Yuriy Bilan ${ }^{1 *}$, Hafezali Iqbal Hussain ${ }^{2}$, Muhammad Haseeb ${ }^{3}$, Sebastian Kot ${ }^{4}$ \\ 1 *Tomas Bata University in Zlin \\ Mostni 5139, 76001 Zlín, Czech Republic \\ E-mail.yuriy_bilan@yahoo.co.uk; *(corresponding author) \\ 2, 3 Taylor's University \\ Jalan Taylors 1, 47500 Subang Jaya, Selangor, Malaysia \\ ${ }^{2}$ University of Economics and Human Sciences in Warsaw \\ Okopowa 59, 01-043 Warsaw, Poland \\ E-mail. ${ }^{2}$ hafezali.iqbalhussain@taylors.edu.my; ${ }^{3}$ muhammad.haseeb@taylors.edu.my \\ ${ }^{4}$ Czestochowa University of Technology \\ ul. Armii Krajowej 19 B, 42-200 Czestochowa, Poland \\ Faculty of Economic Sciences and IT, North-West University \\ Vaal Triangle Campus, Hendrik Van Eck Blvd, Vanderbijlpark, 1900 Vaal Triangle, South Africa \\ E-mail.sebacat@zim.pcz.czest.pl
}

cross $^{\text {ref }}$ http://dx.doi.org/10.5755/j01.ee.31.1.24045

\begin{abstract}
The purpose of the current study is to examine the mediating role of organizational learning on a firm's capabilities, corporate governance, leadership styles, and the firm's sustainability. Moreover, the innovative culture used as a moderating variable between organizational learning and the firm's sustainability. Data were collected from manufacturing organizations operating in Malaysia. This study used simple random sampling technique in data collection. Cross-sectional design and correlational design were used in meeting the objectives of the research. There were 550 questionnaires distributed among respondents, and only 382 questionnaires were returned back, 15 questionnaires were excluded from the 382 questionnaires because of misleading and missing values. Hence, in the final analysis, only 367 questionnaires were used. Findings reveal that organizational capabilities and corporate governance significantly enhance both organizational learning and a firm's sustainability. Moreover, leadership styles significantly enhance organizational learning but have no influence on a firm's sustainability. Organizational learning significantly mediates between organizational capabilities, corporate governance, leadership styles, and the firm's sustainability. Organizational learning also has a significant influence on the firm's sustainability. Finally, innovative culture significantly moderates between organizational learning and the firm's sustainability. The practical contribution of this research is that the top management can focus on these indicators in measuring firm's sustainability.
\end{abstract}

Keywords: Firm's Sustainability; Corporate Governance; Organizational Capabilities; Leadership Styles; Organizational Learning; Innovative Culture.

\section{Introduction}

Firm's sustainability becomes an important indicator for various developing nations, enterprises, and organizations. In the last 30 years, organizations have been rapidly moving to sustainability by getting an advantage over competitors (Oppen \& Brugman, 2009). Firm's sustainability helps in promoting and attaining superior organizational performance and productivity in the markets as well as environments (Ussahawanitchakit, 2017; Shpak, Satalkina, Sroka, \& Hittmar, 2017; Gavurova, Kocisova, Behun \& Tarhanicova, 2018). In the highly rigorous, rapidly changing marketplace and environments, growth, stability, success, continued existence, and sustainability are required to carry out business (Ussahawanitchakit, 2017; Bilan et al., 2017).

Manufacturing sector plays an important role in Malaysia and shows some good statistics. In Malaysia, manufacturing industry sales grew by $6.8 \%$ in April 2019 and total registered sales was 69.9 billion ringgits, while the sales of this industry was 65.5 billion ringgits one year ago (Department of Statistics Malaysia, 2019). The year-on-year growth registered in sales value in April 2019 was driven by the increase in Non-Metallic Mineral Products, Basic Metal \& Fabricated Metal Products $(7.5 \%)$ and Electrical \& Electronics Products $(6.7 \%)$ and Petroleum, Chemical, Rubber \& Plastic Products $(5.8 \%$ ) (Department of Statistics Malaysia, 2019). Malaysian manufacturing industry is the most hazardous industry because of its unique nature (Hong, Ramayah, \& Subramaniam, 2018). This study attempts to reveal the factors that influence manufacturing sector's performance. In this study, organizational learning is used to explain the association between organizational capabilities, leadership styles, and corporate governance with the firm's sustainability in manufacturing industry in Malaysia. 
Moreover, it examines the moderating effect of innovative culture between organizational learning and a firm's sustainability (Zainol et al., 2018; Mustapa et al., 2019).

Organizational capabilities significantly enhance the organizational performance, which helps to attain a sustainable advantage (Zehir \& Acar, 2006). Various researchers use the words "capability", "ability", and "competence" interchangeably (Ulrich \& Smallwood, 2004). In this study, organizational capabilities are used in line with the resource-based view theory. Organizational capabilities are considered an important factor in determining firm's superior performance (Obeidat et al., 2017). This study covers three dimensions of organizational capabilities such as external stakeholders' relations capability, strategic management capability, and operational capability. Leadership styles are another factor that is an important indicator in determining the firm's sustainability. Effective leadership is considered a significant factor that determines failure or success of any kind of a firm (Tourish, 2014; Valickas et al., 2017). Moreover, leadership is a vital element for industries and a critical success factor that leads to firm's sustainability. The basic objective of firms is to focus on their monetary efficiency but at the same time organizations consider their leaders to maintain their sustained competitive advantage in an existing marketplace (Wang, Chich-Jen, \& Mei-Ling, 2010).

Corporate governance is also considered a vital element for organizations in attaining sustained competitive advantage. Nowadays, organizations are progressing under stress for good governance and sustainability (Hussain, Grabara, Razimi, \& Sharif, 2019; Mahmood, Kouser, Ali, Ahmad, \& Salman, 2018). Moreover, the authors reveal that corporate governance and organizational sustainability are contemporary business issues and emerging research areas (Mahmood et al., 2018). Researchers argue that corporate governance and sustainability are vital for the organizations. therefore, more attention should be paid to corporate governance and sustainability. This is a pioneering research that examines the mediating role of firm's learning on organizational capabilities, leadership, and corporate governance and the firm's sustainability. Moreover, this research determines the moderating role of innovative culture between the firm's learning and the firm's sustainability. The theoretical model of the current research was developed in light of resource-based view (RBV) because this theory is one of the most accepted theories that incorporate both capabilities and resources that are essential in attaining sustained competitive advantage and superior performance (Battisti \& Deakins, 2017).

\section{Literature Review}

Organizational Capabilities: Organizational capabilities refer to the organization ability to organize their intangible as well as tangible resources to perform an activity in attaining superior performance and sustained competitive advantage. This study covers three elements of organizational capabilities like external stakeholder's relations capability, strategic management capability, and operational capability (Koufteros, Verghese, \& Lucianetti, 2014) because the manufacturing industry of Malaysia faces various issues regarding these elements. Manufacturing industry faces issues regarding external stakeholder's relations capabilities like relationship with customers and suppliers, issues regarding strategic management capabilities like poor planning, and issues regarding operational capabilities like poor states of technology and process.

Organizational capabilities are considered as internal strengths of organizations that examines how an organization attains competitive advantage and the final outcome is enhanced performance (J. Barney, 1991). Researchers found that organizational capabilities significantly influence organizational learning that ultimately influences sustained competitive advantage (Dess et al., 2019). The literature concludes that organizational capabilities have mixed results with sustainable competitive advantage and calls for further study. Furthermore, less attention has been paid on organizational capabilities on organizational learning directly and there is a need to determine this relationship. This research proposed the following hypotheses:

$H_{l}$ : Organizational capabilities significantly influence the firm's sustainability.

$\mathrm{H}_{2}$ : Organizational capabilities significantly influence organizational learning.

$H_{3}$ : Organizational learning significantly mediates between organizational capabilities and firm's sustainability.

Leadership Styles: Leadership means the ability of an individual to encourage, persuade, and facilitates others to adds to the success of an enterprise. Likewise, leaders the individuals that facilitates their followers by performing the job first then say to subordinates to perform the job; leaders do not eat first they care their subordinates; and leaders create new opportunities for followers, the general public, and for firms. Prior studies demonstrate that Bass leadership is the leading typology (Yahaya \& Ebrahim, 2016; Borkowski et al., 2015). According to Bass (1985), leadership styles covers transactional and transformational. Transformational leadership refers a phenomenon where a leader expects that their subordinates perform well (Bass, 1995) and transform subordinates own values and self-concepts, and convert them to a greater level of needs and ambitions (Jung, 2001). Transactional leadership involves an exchange of relationship between leaders and subordinates such as subordinates collect wages and prestige for obeying job or task from the leader's side. Some of the researchers elucidate that transformational leadership is vital in determining the firm's learning (Nafei, Khanfar, \& Kaifi, 2012; Theodore, 2013; Mishchuk et al., 2018). In addition, literature investigates the relationship of transactional leadership with organizational learning and found that transactional leadership significantly enhances organizational learning. RBV theory suggests that organizational learning can significantly explain the relationship between leadership styles that is organizational resource and firms sustainability (J. B. Barney, 1991). This study proposed the following hypotheses:

$\mathrm{H}_{4}$ : Leadership styles significantly influence firm's the sustainability.

$\mathrm{H}_{5}$ : Leadership styles significantly influence organizational learning.

$\mathrm{H}_{6}$ : Organizational learning significantly mediates between leadership styles and firm's sustainability.

Corporate Governance: The term corporate governance means a complex group of the controls that form the ex-post bargaining over the quasi-rents that produced by the 
organization (Zingales, 1998). Moreover, authors recommend that corporate governance connected with economic interests of participants within organizations. Nowadays, both organizations and researchers pay more attention to corporate governance after happening a big scandal in the Enron and the WorldCom (Ali, 2018). Particularly, in the emerging nations, the proper structure of governance provides a vital objective for the betterment of organizations and reduces the chance of financial loss and the conflicts within organization management (Berinde, 2018; Salem, Shawtari, Shamsudin, $\&$ Hussain, 2018). Board size means the strength of nonexecutive and executive directors. Agency theory concludes that a smaller board is more beneficial than a larger board because smaller board size has higher managerial controls (Jensen \& Meckling, 1976). Agency theory highlights the major conflicts between the agent (CEO) and principal (board) because the firm's agents mostly work for their own betterment instead of principal betterment. Hence, there is a need for some independent directors on the board that honestly look after the performance of agents (Huse, 1994). A meta-analysis conducted on board independence and business sustained performance that there are some inconclusive results between these variables (Dalton, Daily, Ellstrand, \& Johnson, 1998). Few of the studies demonstrate that board independence enhances their performance and sustainability (Alias, Yaacob, \& Jaffar, 2017; Baysinger \& Butler, 1985). Literature regarding board diversity found that it plays a crucial role in minimizing uncertainty and improving firms sustained performance (Hillman \& Dalziel, 2003). In contrast, few of the researchers found that board diversity significantly reduce firms performance that ultimately effects sustained competitive advantage (Arena et al., 2015). Another factor of corporate governance is the board meeting in a year important for performance and sustainability. Board committee can give better results in that situation where this committee includes some nonexecutive members and these members should be independent not depend on the organization (Lam \& Lee, 2012). The literature demonstrates that board committees have a significant influence on firms sustainability and their performance but researchers paid more attention in developed countries (Puni, 2015). This research proposed the following hypotheses:

$\mathrm{H}_{7}$ : Corporate governance significantly influences firm's sustainability.

$\mathrm{H}_{8}$ : Corporate governance significantly influences organizational learning

$\mathrm{H}_{9}$ : Organizational learning significantly mediates between corporate governance and firm's sustainability.

Organizational Learning and Innovative culture: Organizational learning is considered a significant element for organizations in determining superior performance and sustained competitive advantage (Hailekiros \& Renyong, 2016). Likewise, another researcher reveals that organizational learning is a vital element in the organizations that explains performance. Few of the studies investigate the relationship between learning and performance (Hsu, 2014; Poór et al., 2018). Hence, organizational learning can be a crucial factor in examining a firm's sustainability. Few of the researchers provide evidence that organizational culture should be focused on measuring their performance and it cannot be ignored (Gochhayat, Giri, \& Suar, 2017). In addition, literature regarding innovative culture shows that it is vital in enhancing a firm's performance that leads to a firm's sustainability and competitive advantage (Pachura 2017). This study proposed the following hypotheses:

$\mathrm{H}_{10}$ : Organizational learning has a significant influence on the firm's sustainability.

$\mathrm{H}_{11}$ : Innovative culture significantly moderates between organizational learning and the firm's sustainability.

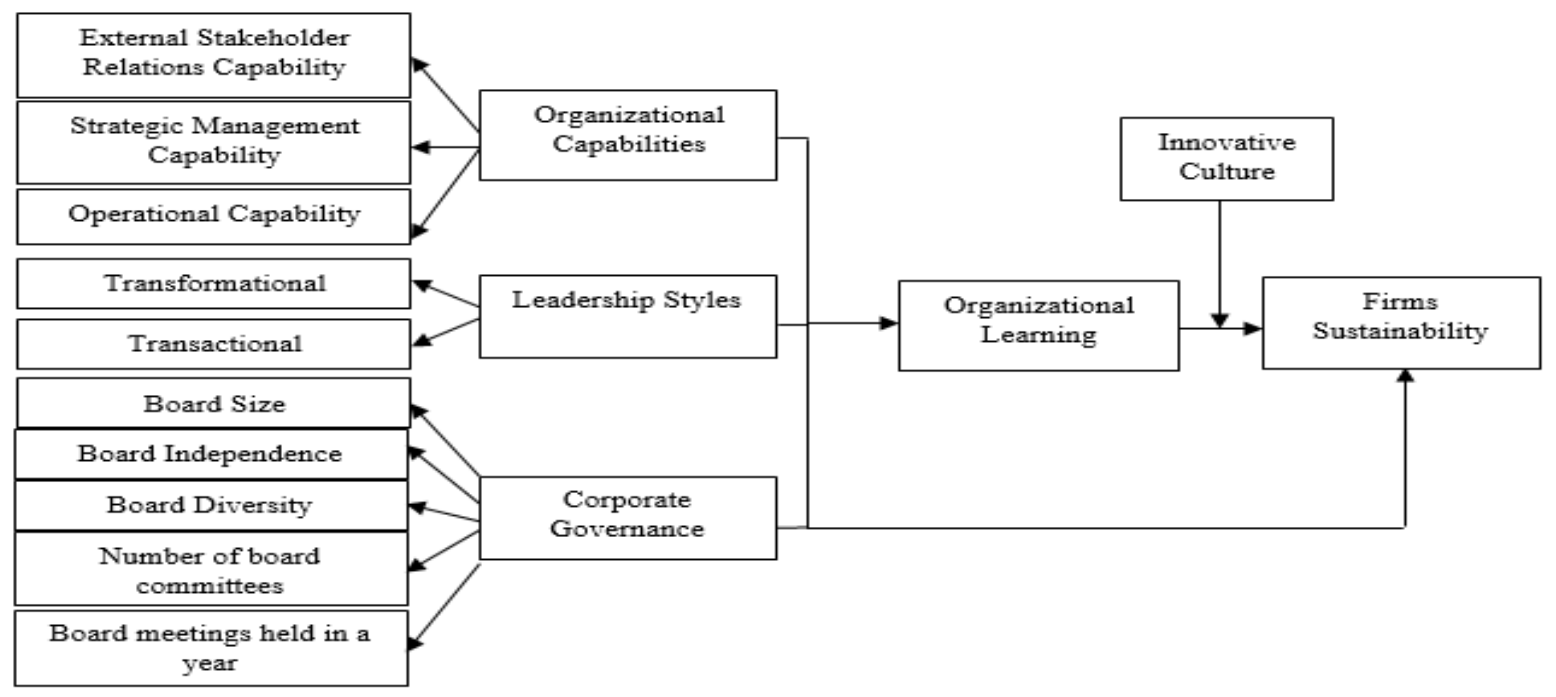

Figure 1. Theoretical Framework

\section{Research Methodology}

This research, to look after nature, objectives, and problem, our study is quantitative and co-relational in nature to collect data by using a questionnaire.

Research Questionnaire: The theoretical framework of current research consists of six constructs that measured by using some items that adapted from prior studies as the reliability and validity of the items has been well established. Every item of particular variables measured by using a 5 Likert scale that range from 1 (strongly disagree) to 5 (strongly agree). Organizational capabilities consists of 15 items from three dimensions like external stakeholders relations capability 4 items, strategic management capability 
6 items, and operational capability 5 items adapted from Koufteros et al. (2014); leadership styles 6 items (transformational 3 items and transactional 3 items) adapted from Avolio and Bass (2002); corporate governance consists 23 items from five dimensions such as board size 5 items, board diversity 6 items, board meetings held in a year 4 items, board independence 3 items, and number of board committees 5 items adapted from Honghui (2017); innovative culture includes 8 items and that items adapted from Wallach (1983); organizational learning includes 4 items and adapted from Hult (1998); and firms sustainability includes 5 items and adapted from (Gelhard \& Von Delft, 2016). After adapting the related instruments, send three questionnaire copies to field experts and three questionnaires to Ph.D. to confirm that instruments fulfil the criterion of face validity. However, field experts and Ph.D. give their opinion that there is no error regarding face validity in the questionnaire.

Population and sampling: In Malaysia, total numbers of manufacturing companies are 39,696 out of which 21,609 are micro, 13,904 are small, 2,308 medium, and 1,808 are large manufacturing companies (Insider, 2019). This research covers 1808 manufacturing large companies working in Malaysia. Data were collected by using simple random sampling approach because this technique is more appropriate when researchers know the population (Sekaran \& Bougie, 2016).

Sample size: Comrey and Lee (1992), there are various ranges of sample size that a researcher can choose. For instance, sample size under 50 is considered weaker, more than 51 and equal to 100 is deemed weak, sample size more than 101 and equals to 200 is deemed adequate, sample size 300 is deemed good, sample size 500 is considered very good and sample size 1000 is considered excellent. In this research, our respondents were general managers. Total of 550 questionnaires distributed among general managers.

\section{Results and Analysis}

The current research used SmartPLS 3.2.8 to determine the theoretical model because this tool is the rapidly raising tool of $2^{\text {nd }}$ generation as recommended (Hair, Hult, Ringle, $\&$ Sarstedt, 2014). In the measurement model, two things are required to calculate that are followings: Convergent and Discriminant validity. This study followed various steps of PLS-SEM from the study of Hameed, Basheer, Iqbal, Anwar, and Ahmad (2018)

Convergent Validity: Figure 2 shows a measurement model that covers organizational capabilities, leadership, and corporate governance as a second-order construct with an innovative culture, firm's learning, and firm's sustainability. This study used repeated indicator technique for organizational capabilities, leadership styles, and corporate governance. This technique runs full model at one click rather than lower order dimensions and higher order separately (Becker, Klein, \& Wetzels, 2012). Table 1 demonstrates that the above-mentioned criterion fulfils regarding AVE, CR, and Cronbach's alpha. AVE above 0.5 confirms the convergent validity.

\section{Convergent Validity}

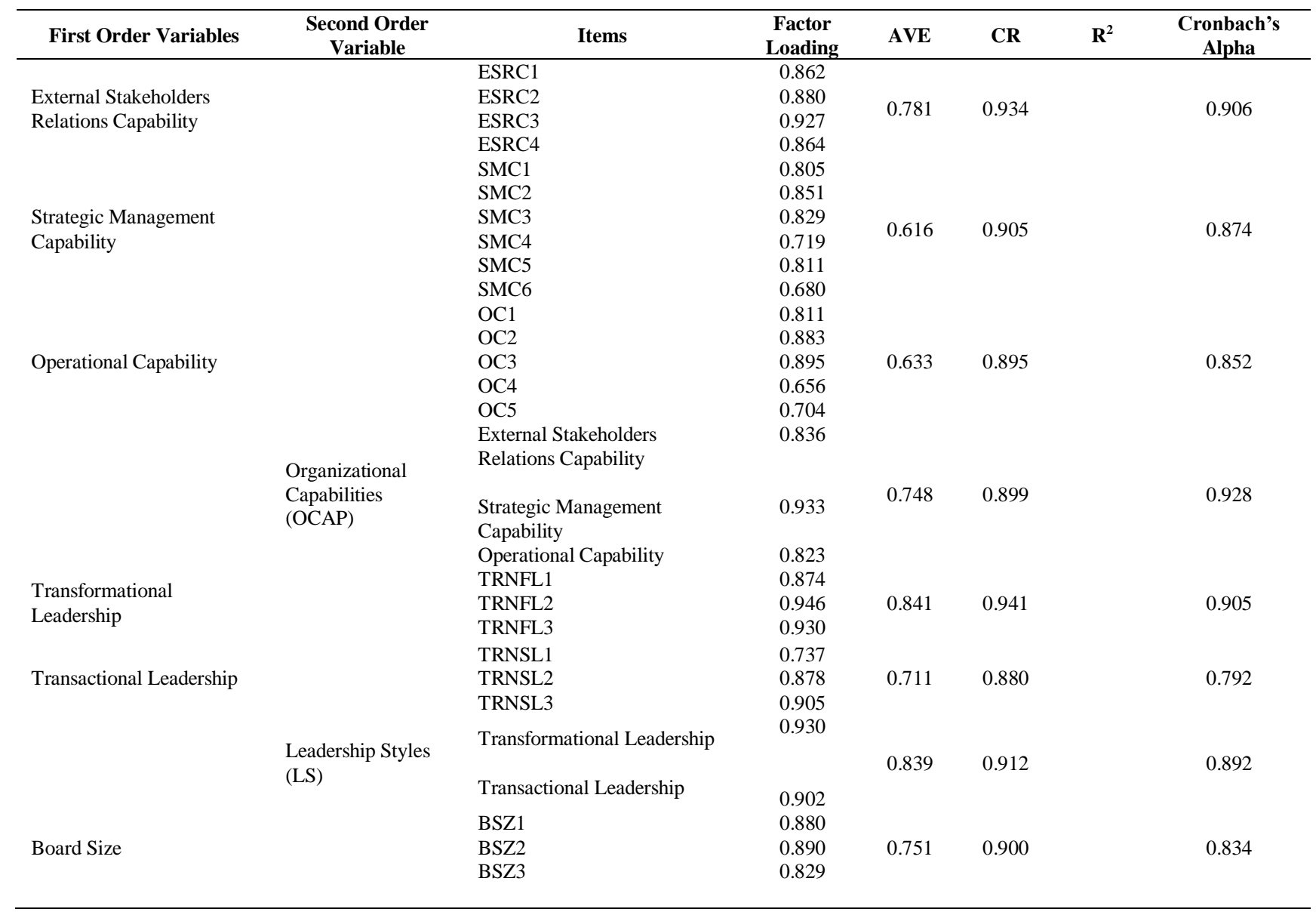

Table 1 
Inzinerine Ekonomika-Engineering Economics, 2020, 31(1), 93-103

\begin{tabular}{|c|c|c|c|c|c|c|c|}
\hline First Order Variables & $\begin{array}{c}\text { Second Order } \\
\text { Variable }\end{array}$ & Items & $\begin{array}{l}\text { Factor } \\
\text { Loading }\end{array}$ & AVE & CR & $\mathbf{R}^{2}$ & $\begin{array}{c}\text { Cronbach's } \\
\text { Alpha }\end{array}$ \\
\hline Board Diversity & & $\begin{array}{l}\text { BDV1 } \\
\text { BDV2 } \\
\text { BDV3 } \\
\text { BDV4 } \\
\text { BDV5 }\end{array}$ & $\begin{array}{l}0.857 \\
0.822 \\
0.693 \\
0.657 \\
0.726\end{array}$ & 0.570 & 0.868 & & 0.813 \\
\hline Board Meetings in a Year & & $\begin{array}{l}\text { BM1 } \\
\text { BM2 } \\
\text { BM3 }\end{array}$ & $\begin{array}{l}0.884 \\
0.927 \\
0.896\end{array}$ & 0.815 & 0.929 & & 0.886 \\
\hline Board Independence & & $\begin{array}{l}\text { BID1 } \\
\text { BID2 } \\
\text { BID3 }\end{array}$ & $\begin{array}{l}0.877 \\
0.878 \\
0.639\end{array}$ & 0.649 & 0.845 & & 0.733 \\
\hline $\begin{array}{l}\text { Number of Board } \\
\text { Committees }\end{array}$ & & $\begin{array}{l}\text { NBCM1 } \\
\text { NBCM2 } \\
\text { NBCM3 }\end{array}$ & $\begin{array}{l}0874 \\
0.904 \\
0.858\end{array}$ & 0.772 & 0.910 & & 0.852 \\
\hline & $\begin{array}{l}\text { Corporate } \\
\text { Governance } \\
\text { (CG) }\end{array}$ & $\begin{array}{l}\text { Board Size } \\
\text { Board Diversity } \\
\text { Board Meetings in a Year } \\
\text { Board Independence } \\
\text { Number of Board Committees }\end{array}$ & $\begin{array}{l}0.821 \\
0.872 \\
0.801 \\
0.813 \\
0.822\end{array}$ & 0.682 & 0.914 & & 0.917 \\
\hline $\begin{array}{l}\text { Organizational Learning } \\
(\mathrm{OL})\end{array}$ & & $\begin{array}{l}\text { OL1 } \\
\text { OL2 } \\
\text { OL3 } \\
\text { OL4 }\end{array}$ & $\begin{array}{l}0.833 \\
0.847 \\
0.840 \\
0.834\end{array}$ & 0.703 & 0.905 & 0.341 & 0.860 \\
\hline $\begin{array}{l}\text { Innovative Culture } \\
\text { (INVCL) }\end{array}$ & & $\begin{array}{l}\text { INVCL1 } \\
\text { INVCL2 } \\
\text { INVCL4 } \\
\text { INVCL6 } \\
\text { INVCL7 }\end{array}$ & $\begin{array}{l}0.754 \\
0.856 \\
0.846 \\
0.626 \\
0.508\end{array}$ & 0.533 & 0.847 & & 0.773 \\
\hline $\begin{array}{l}\text { Firms Sustainability } \\
\text { (FRS) }\end{array}$ & & $\begin{array}{l}\text { FRS1 } \\
\text { FRS2 } \\
\text { FRS3 } \\
\text { FRS4 } \\
\text { FRS5 }\end{array}$ & $\begin{array}{l}0.730 \\
0.793 \\
0.877 \\
0.797 \\
0.823\end{array}$ & 0.649 & 0.902 & 0.446 & 0.864 \\
\hline
\end{tabular}

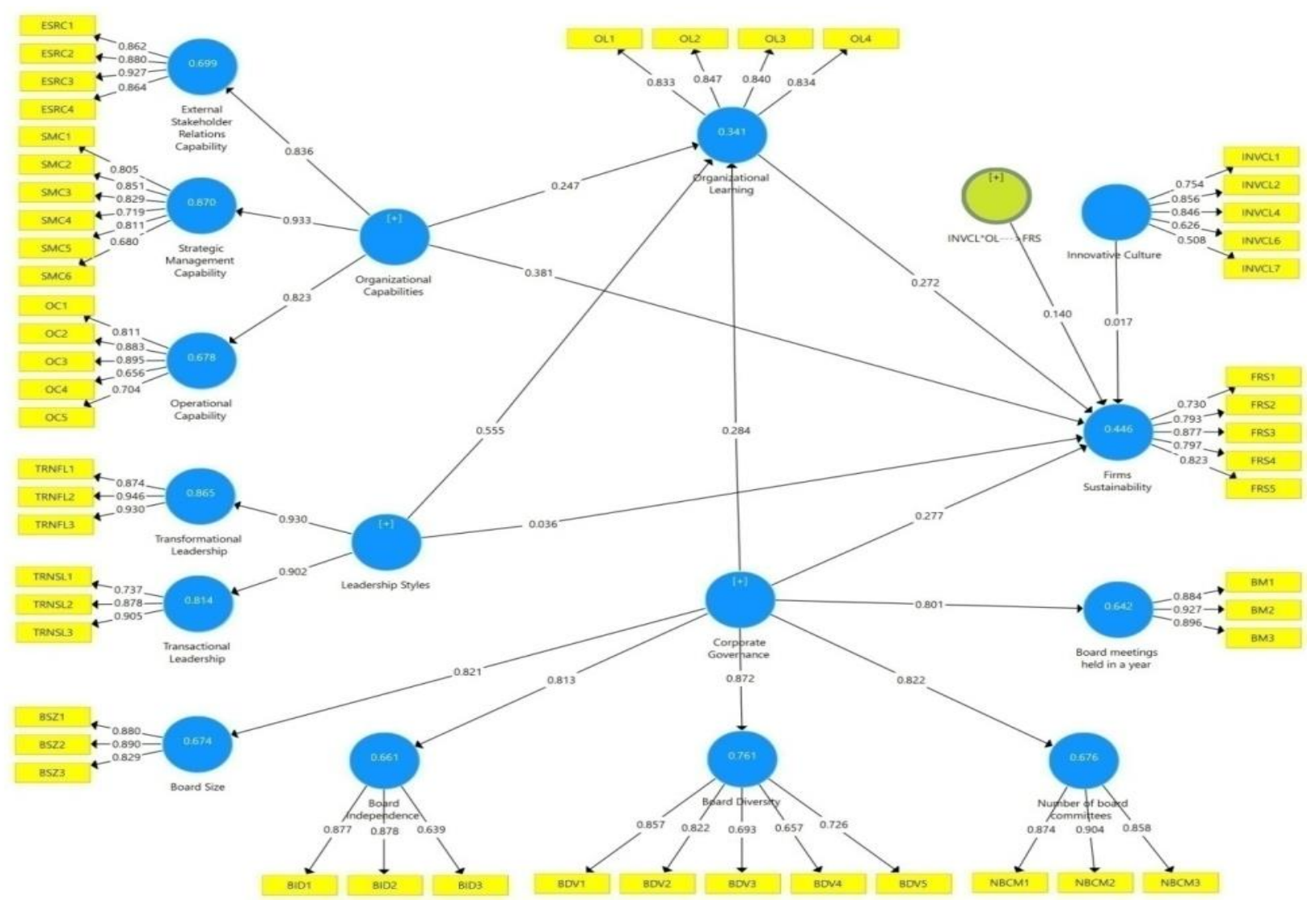

Figure 2. Measurement Model 
Yuriy Bilan, Hafezali Iqbal Hussain, Muhammad Haseeb, Sebastian Kot. Sustainability and Economic Performance: Role...

Discriminant validity: In this study, AVE square root used to calculate discriminant validity. The upper diagonal values of Discriminant validity table should be higher than remaining values in the same column and same row (Fornell \& Larcker, 1981). Table 2 shows that current research fulfils Discriminant validity criterion.

Table 2

Discriminant Validity

\begin{tabular}{|c|c|c|c|c|c|c|c|c|}
\hline Variables & Mean & S.D & OCAP & LS & $\mathrm{CG}$ & $\mathrm{OL}$ & INVCL & FRS \\
\hline OCAP & 3.96 & 0.718 & 0.865 & & & & & \\
\hline LS & 4.00 & 0.764 & $0.435^{* *}$ & 0.917 & & & & \\
\hline $\mathrm{CG}$ & 3.84 & 0.732 & $0.432 * *$ & $0.235^{*}$ & 0.826 & & & \\
\hline $\mathrm{OL}$ & 3.93 & 0.825 & $0.125^{*}$ & $0.513 * *$ & $0.288 * *$ & 0.839 & & \\
\hline INVCL & 3.95 & 0.727 & $0.803^{* *}$ & $0.344 * *$ & $0.422 * *$ & 0.076 & 0.730 & \\
\hline FRS & 3.79 & 0.897 & $0.502^{* *}$ & $0.290 * *$ & $0.482^{* *}$ & 0.369 & $0.409^{* *} *$ & 0.805 \\
\hline
\end{tabular}

Structural Model and Hypotheses Testing: This research followed PLS bootstrapping method and runs bootstrapping with 5000 subsamples. Table 3 and 4 demonstrated that this research includes 11 hypotheses.

Table 3

\section{Direct and Mediating Relationships}

\begin{tabular}{|c|c|c|c|c|c|c|}
\hline Hypotheses & Paths & $\begin{array}{l}\text { Original } \\
\text { Sample }\end{array}$ & Std. Dev. & T-values & P-values & Findings \\
\hline $\mathrm{H}_{1}$ & OCAP --> FRS & 0.381 & 0.086 & 4.448 & 0.000 & Significant \\
\hline $\mathrm{H}_{2}$ & OCAP $-->$ OL & 0.247 & 0.060 & 4.135 & 0.000 & Significant \\
\hline $\mathrm{H}_{3}$ & OCAP-> OL-> FRS & 0.067 & 0.023 & 2.992 & 0.003 & Significant \\
\hline $\mathrm{H}_{4}$ & LS --> FRS & 0.036 & 0.067 & 0.534 & 0.594 & Not Significant \\
\hline $\mathrm{H}_{5}$ & LS --> OL & 0.555 & 0.049 & 11.241 & 0.000 & Significant \\
\hline $\mathrm{H}_{6}$ & LS-> OL-> FRS & 0.151 & 0.042 & 3.598 & 0.000 & Significant \\
\hline $\mathrm{H}_{7}$ & CG $-->$ FRS & 0.277 & 0.056 & 4.995 & 0.000 & Significant \\
\hline $\mathrm{H}_{8}$ & CG --> OL & 0.284 & 0.055 & 5.246 & 0.000 & Significant \\
\hline $\mathrm{H}_{9}$ & CG-> OL-> FRS & 0.077 & 0.023 & 3.392 & 0.001 & Significant \\
\hline $\mathrm{H}_{10}$ & OL --> FRS & 0.272 & 0.069 & 3.964 & 0.000 & Significant \\
\hline
\end{tabular}

$O C A P=$ Organizational capabilities; $L S=$ Leadership styles; $C G=$ Corporate governance $;$ OL=Organizational learning; INVCL=Innovative culture; FRS=Firms sustainability

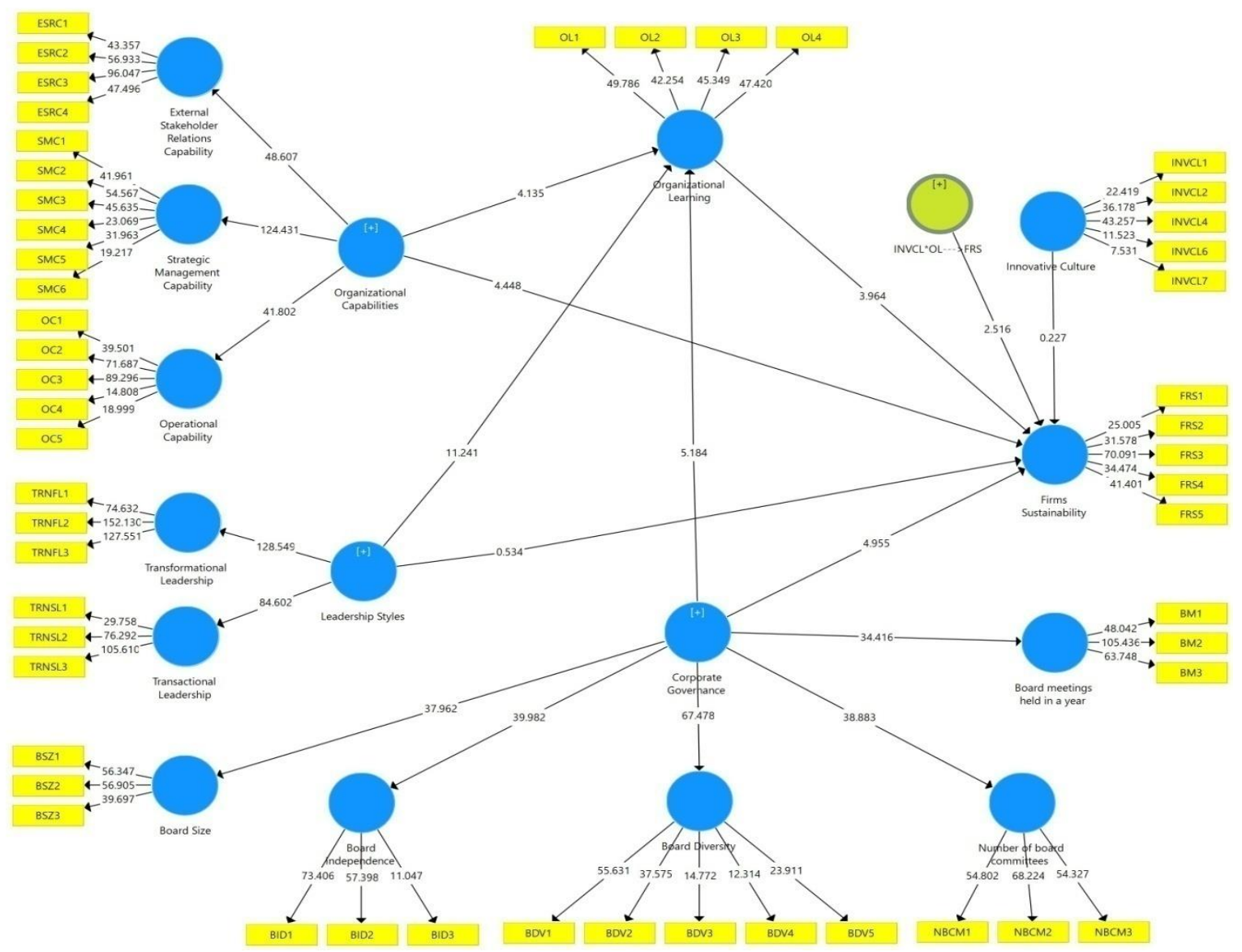

Figure 3. Structural Model 
Results: Table 3 shows that organizational capabilities significantly enhance firms' sustainability as $\mathrm{t}=4.448$ and $\mathrm{p}$ value 0.000 and $\mathrm{H}_{1}$ accepted. Moreover, organizational capabilities significantly improve organizational learning as $\mathrm{t}=4.135$ and $\mathrm{p}$-value below 0.05 and $\mathrm{H} 2$ supported. Organizational learning significantly mediates between organizational capabilities and the firm's sustainability as tvalue 2.992 and p-value 0.003 and accepted $\mathrm{H}_{3}$. Leadership styles have no influence on firm's sustainability as t-value 0.534 and p-value greater than 0.05 and $\mathrm{H}_{4}$ not supported. Moreover, leadership significantly increase organizational learning as $\mathrm{t}=11.241$ and $\mathrm{p}$-value less than 0.05 and $\mathrm{H}_{5}$ accepted. Organizational learning positively explains the between leadership styles and firm's sustainability as t-value 3.598 and p-value less than 0.05 and supported $\mathrm{H}_{6}$. Corporate governance significantly enhances the firm's sustainability as t-value 4.995 and p-value below 0.05 and supported $\mathrm{H}_{7}$. Moreover, corporate governance significantly enhances organizational learning as $\mathrm{t}=5.246$ and $\mathrm{p}$ value $=0.000$ and accepted $\mathrm{H}_{8}$. Corporate learning significantly and positively explains the relationship between corporate governance and firm's sustainability as $\beta=0.077, t=3.392$, and $p$-value $=0.001$ and $\mathrm{H}_{9}$ accepted. Organizational learning significantly and positively enhances firm's sustainability as $\beta=0.272, \mathrm{t}=3.964$, and $\mathrm{p}$ value less than 0.05 and $\mathrm{H}_{10}$ supported.

Testing the moderating effect: In this research, we focused on product indicator technique to test the moderating role of innovative culture through PLS structural equation modeling approach and Cohen (1988) effect size criteria used to recognize and compute the strength of moderating effect.

Indirect Hypotheses Results (Moderation)

Table 4

\begin{tabular}{ccccccc}
\hline Hypotheses & Paths & Original Sample & Std. Dev. & T-values & P-values & Results \\
\hline $\mathrm{H}_{11}$ & INVCL*OL->FRS & 0.140 & 0.056 & 2.516 & 0.012 & Significant \\
\hline
\end{tabular}

Table 4 shows that innovative culture positively and significantly moderates between organizational learning and the firm's sustainability as t-value 2.516 , and p-value 0.012

and $\mathrm{H}_{11}$ accepted. Figure 4 show that innovative culture strengthens the positive relationship between organizational learning and firm's sustainability.

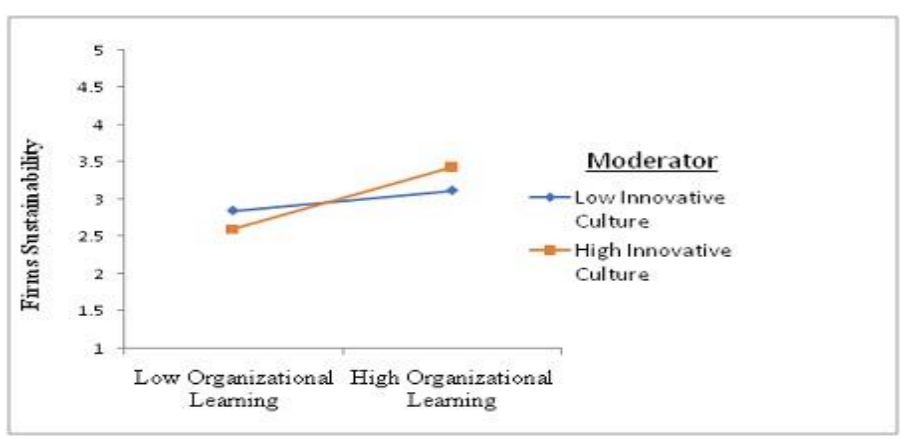

Figure 4. Innovative Culture Moderate between Organizational Learning and Firm's Sustainability

The predictive relevance of the theoretical model: Predicative relevance $\left(\mathrm{Q}^{2}\right)$ shows the quality of the model. Its value should be above zero. Hence, the current study fulfils this criterion regarding $\mathrm{Q}^{2}$, as of $\mathrm{Q}^{2}$ of organizational learning 0.224 and firm's sustainability 0.266 as revealed in Table 5. Additionally, r-square is also shown in Table 5 which is acceptable.

The Predictive Relevance of Theoretical Framework and $\mathbf{Q}^{2}$

\begin{tabular}{lcccc}
\hline Total & $\mathrm{R}^{2}$ & $\mathrm{SSO}$ & $\mathrm{SSE}$ & $\mathrm{Q}^{2}(=1-\mathrm{SSE} / \mathrm{SSO})$ \\
\hline Organizational learning & 0.341 & 1468.000 & 1139.141 & 0.224 \\
Firms sustainability & 0.446 & 1835.000 & 1347.419 & 0.266 \\
\hline
\end{tabular}

\section{Discussion}

The aim of the current research is to examine the mediating effect of corporate learning between organizational capabilities, leadership, corporate governance, and firm's sustainability. In addition, determines the moderating role innovative culture between organizational learning and the firm's sustainability. The findings elucidated that organizational capabilities significantly enhance the firm's sustainability, and supported $\mathrm{H}_{1}$ and consistent with various studies which shows that organizational capabilities significantly improve organizational performance that leads to firm's sustainability. Organizational capabilities significantly enhance organizational learning and supported $\mathrm{H}_{2}$. The findings are similar with (Dess et al., 2019) that organizational capabilities significantly enhance sustained competitive advantage. Organizational learning significantly mediates between organizational capabilities and the firm's sustainability and $\mathrm{H}_{3}$ supported. Leadership styles have no influence on the firm's sustainability and $\mathrm{H}_{4}$ not supported. The findings are similar with (Podolny, Khurana, \& HillPopper, 2005) that leadership styles not important in determining sustained competitive advantage. Moreover, leadership styles significantly and positively influence organizational learning and supported $\mathrm{H}_{5}$ and consistent with 
(Nafei et al., 2012; Theodore, 2013). Organizational learning significantly explains leadership styles and the firm's sustainability and supported $\mathrm{H}_{6}$.

Corporate governance significantly enhances the firm's sustainability and supported $\mathrm{H}_{7}$ and similar with (Shrivastava \& Addas, 2014) that corporate governance leads to firms higher sustainability. Corporate governance significantly improves organizational learning and supported our hypotheses $\mathrm{H}_{8}$. Organizational learning significantly mediates between corporate governance and firm's sustainability and our hypotheses H9 accepted. Organizational learning significantly enhances the firm's sustainability and supported $\mathrm{H}_{10}$. The outcomes are similar to (Kim et al., 2017). Innovative culture significantly moderates between organizational learning and the firm's sustainability and supported $\mathrm{H}_{11}$. It means that organizational learning plays a vital role in enhancing firm's sustainability and innovative culture strengthen the relationship between organizational learning and firm's sustainability.

Theoretical implications: This research examines the mediating role of firms learning between organizational capabilities, corporate governance, leadership styles, and firm's sustainability that ignores in prior studies. In addition, current research examines the moderating effect of innovative culture between the firm's learning and the firm's sustainability that researchers ignore. By incorporating organizational capabilities, corporate governance, leadership, firm's learning, innovative culture, and firm's sustainability in one model, this research settles a ground for new researchers to work on this area. In addition, organizational learning can further be used in explaining the association between organizational capabilities, corporate governance, leadership styles, and the firm's sustainability. This is the pioneering research that used firms learning as a mediating construct between second-order variables (organizational capabilities, corporate governance, leadership styles), and firms' sustainability by using RBV theory. This study confirms the RBV theory that organizational learning significantly and positively explains organizational capabilities, corporate governance, leadership styles, and firm's sustainability.

Practical Implications: The results of current research have a number of practical implications for the top management of organizations. This research revealed that organizational capabilities (external stakeholder's relations capability, strategic management capability, and operational capability) and corporate governance (board size, board diversity, board independence, board meetings in a year, and a number of board committees) has played a significant role in enhancing organizational learning and firm's sustainability. Leadership styles are vital in determining organizational learning, but it has no influence on the firm's stability in this research. These findings clearly give a message to the top management of manufacturing industry that only leadership styles do not give fruitful results but there is a need to focus some other variable with leadership styles to measure firm's sustainability. Top management cannot ignore leadership styles because leadership provides significant results in other countries and some other contexts. Therefore, the current study suggests top management of manufacturing industry to focus on organizational capabilities and corporate governance in measuring the firm's sustainability.

Limitations and suggestions: This research entirely work on manufacturing industry of Malaysia. Even though the findings of this study significantly provide contributions to the literature about organizational capabilities, corporate governance, leadership styles, organizational learning, innovative culture, and firms sustainability, but the outcomes of this study cannot be generalized in the whole world. Hence, in the future, there is a need to study further the theoretical model of the current study in other countries to generalize the results. In addition, in this research, our focus was only on firm's capabilities, leadership, corporate governance, corporate learning, and innovative culture in examining the firm's sustainability. In the future, there is a need to focus on management control systems as a package and business strategy in determining the firm's sustainability in developed and developing countries. The current research developed a theoretical model on the basis of RBV theory and in future, there is a need to focus resource orchestration theory to determine the association between corporate governance, leadership styles, and firm's sustainability with the help organizational capabilities as a mediating variable.

\section{Conclusion}

This research reveals that organizational capabilities (external stakeholders' relations capability, strategic management capability, and operational capability), corporate governance (size, diversity, independence, meetings in a year, and a number of committees), and leadership styles (transactional and transformational leadership) significantly enhances organizational learning. Researchers cannot overlook these factors in measuring organizational learning. Moreover, organizational capabilities, corporate governance, and organizational learning significantly improve the firm's sustainability. Despite this, leadership styles have no influence on the firm's sustainability. Moreover, organizational learning significantly mediates between all three independent constructs like organizational capabilities, corporate governance, leadership styles, and the firm's sustainability. Innovative culture significantly moderates between organizational learning and a firm's sustainability. Hence, the findings of this study confirm the RBV theory.

\section{References}

Ali, M. (2018). Impact Of Corporate Governance On Firm's Financial Performance (A Comparative Study Of Developed And Non Developed Markets). Economic Research, 2(1), 15-30. https://doi.org/10.29226/TR1001.2018.7

Alias, N., Yaacob, M., \& Jaffar, N. (2017). Governance structure, corporate restructuring and performance. A Journal of Management Studies, 15(1), 7-14. 
Arena, C., Cirillo, A., Mussolino, D., Pulcinelli, I., Saggese, S., \& Sarto, F. (2015). Women on board: evidence from a masculine industry. Corporate Governance, 15(3), 339-356. https://doi.org/10.1108/CG-02-2014-0015

Avolio, B., \& Bass, B. M. (2002). Manual for the multifactor leadership questionnaire (Form 5X): Redwood City, CA: Mindgarden.

Barney, J. (1991). Firm resources and sustained competitive advantage. Journal of management, 17(1), 99-120. https://doi.org/10.1177/014920639101700108

Bass, B. M. (1985). Leadership and performance beyond expectations: Collier Macmillan.

Bass, B. M. (1995). Comment: Transformational leadership: Looking at other possible antecedents and consequences. Journal of Management Inquiry, 4(3), 293-297. https://doi.org/10.1177/105649269543010

Battisti, M., \& Deakins, D. (2017). The relationship between dynamic capabilities, the firm's resource base and performance in a post-disaster environment. International Small Business Journal, 35(1), 78-98. https://doi.org/10. $1177 / 0266242615611471$

Baysinger, B. D., \& Butler, H. N. (1985). Corporate governance and the board of directors: Performance effects of changes in board composition. Journal of Law, Economics, \& Organization, 1(1), 101-124.

Becker, J.-M., Klein, K., \& Wetzels, M. (2012). Hierarchical latent variable models in PLS-SEM: guidelines for using reflective-formative type models. Long Range Planning, 45(5-6), 359-394. https://doi.org/10.1016/j.lrp.2012. 10.001

Berinde, S. R. (2018). Corporate Governance Decisions in Accounting Business Field for Increasing Competitiveness. Romania, France and Europe Comparison. Inzinerine Ekonomika-Engineering Economics, 29(3), $302-311$. https://doi.org/10.5755/j01.ee.29.3.17269

Bilan, Y., Gavurova, B., Stanisław, G., \& Tkacova, A. (2017). The Composite Coincident Indicator (CCI) for Business Cycles. Acta Polytechnica Hungarica, 14(7), 71-90. https://doi.org/10.12700/APH.14.7.2017.7.5

Cohen, J. (1988). Statistical power analysis for the behavioral sciences: Routledge.

Comrey, A. L., \& Lee, H. B. (1992). A first course in factor analysis: Psychology Press.

Dalton, D. R., Daily, C. M., Ellstrand, A. E., \& Johnson, J. L. (1998). Meta-analytic reviews of board composition, leadership structure, and financial performance. Strategic management journal, 19(3), $269-290$. https://doi.org/10.1002/(SICI)1097-0266(199803)19:3<269::AID-SMJ950>3.0.CO;2-K

Department of Statistics Malaysia, O. P. (2019). Manufacturing, Monthly Manufacturing Statistics Malaysia, April 2019. Retrieved from https://dosm.gov.my/v1/index.php?r=column/ctwoByCat\&parent_id=89\&menu_id=SjgwNXdiM0 JIT3Q2TDBlWXdKdUVldz09

Dess, G. G., McNamara, G., Eisner, A. B., \& Lee, S. H. (2019). Strategic Management: Creating Competitive Advantages: McGraw-Hill Education.

Fornell, C., \& Larcker, D. F. (1981). Evaluating structural equation models with unobservable variables and measurement error. Journal of marketing research, 18(1), 39-50. https://doi.org/10.1177/002224378101800104

Gavurova, B., Kocisova, K., Behun, M., \& Tarhanicova, M. (2018). Environmental performance in OECD countries: A non-radial DEA approach. Acta Montanistica Slovaca, 23(2), 206-215.

Gelhard, C., \& Von Delft, S. (2016). The role of organizational capabilities in achieving superior sustainability performance. Journal of Business Research, 69(10), 4632-4642. https://doi.org/10.1016/j.jbusres.2016.03.053

Gochhayat, J., Giri, V. N., \& Suar, D. (2017). Influence of Organizational Culture on Organizational Effectiveness: The Mediating Role of Organizational Communication. Global Business Review, 18(3), 691-702. https://doi.org/10. 1177/0972150917692185

Hailekiros, G. S., \& Renyong, H. (2016). The effect of organizational learning capability on firm performance: Mediated by technological innovation capability. European Journal of Business Management, 8(30), 87-95.

Hair, J. F., Hult, G. T. M., Ringle, C., \& Sarstedt, M. (2014). A primer on partial least squares structural equation modeling (PLS-SEM). Thousand Oaks: Sage Publications.

Hameed, W. U., Basheer, M. F., Iqbal, J., Anwar, A., \& Ahmad, H. K. (2018). Determinants of Firm's open innovation performance and the role of R \& D department: an empirical evidence from Malaysian SME's. Journal of Global Entrepreneurship Research, 8(1), 29. https://doi.org/10.1186/s40497-018-0112-8

Hillman, A. J., \& Dalziel, T. (2003). Boards of directors and firm performance: Integrating agency and resource dependence perspectives. Academy of Management review, 28(3), 383-396. https://doi.org/10.5465/ amr.2003. 10196729

Hong, C. C., Ramayah, T., \& Subramaniam, C. (2018). The relationship between critical success factors, internal control and safety performance in the Malaysian manufacturing sector. Safety science, 104, 179-188. https://doi.org/10. 1016/j.ssci.2018.01.002 
Yuriy Bilan, Hafezali Iqbal Hussain, Muhammad Haseeb, Sebastian Kot. Sustainability and Economic Performance: Role...

Honghui, L. (2017). The effect of Corporate Governance on Performance of firms listed on the nairobi securities exchange. School of business, University of Nairobi.

Hsu, S. H. (2014). Effects of organization culture, organizational learning and IT strategy on knowledge management and performance. The Journal of International Management Studies, 9(1), 50-58.

Hult, G. T. M. (1998). Managing the international strategic sourcing process as a market-driven organizational learning system. Decision Sciences, 29(1), 193-216. https://doi.org/10.1111/j.1540-5915.1998.tb01349.x

Huse, M. (1994). Board-management relations in small firms: The paradox of simultaneous independence and interdependence. Small Business Economics, 6(1), 55-72. https://doi.org/10.1007/BF01066112

Hussain, H. I., Grabara, J., Razimi, M. S. A., \& Sharif, S. P. (2019). Sustainability of Leverage Levels in Response to Shocks in Equity Prices: Islamic Finance as a Socially Responsible Investment. Sustainability, 11(12), 3260. https://doi.org/10.3390/su11123260

Insider, e. (2019). Malaysia's SME statistics, and e-commerce readiness. Retrieved from https://www.ecinsider.my/ 2013/12/ malaysia- sme- statistics-ecommerce-readiness.html

Jensen, M. C., \& Meckling, W. H. (1976). Theory of the firm: Managerial behavior, agency costs and ownership structure. Journal of financial economics, 3(4), 305-360. https://doi.org/10.1016/0304-405X(76)90026-X

Jung, D. I. (2001). Transformational and transactional leadership and their effects on creativity in groups. Creativity Research Journal, 13(2), 185-195. https://doi.org/10.1207/S15326934CRJ1302_6

Kim, K., Watkins, K. E., \& Lu, Z. (2017). The impact of a learning organization on performance: Focusing on knowledge performance and financial performance. European Journal of Training and Development, 41(2), $177-193$. https://doi.org/10.1108/EJTD-01-2016-0003

Koufteros, X., Verghese, A. J., \& Lucianetti, L. (2014). The effect of performance measurement systems on firm performance: A cross-sectional and a longitudinal study. Journal of Operations Management, 32(6), $313-336$. https://doi.org/10.1016/j.jom.2014.06.003

Lam, T. y., \& Lee, S. k. (2012). Family ownership, board committees and firm performance: evidence from Hong Kong. Corporate Governance: The international journal of business in society, 12(3), 353-366. https://doi.org/10.1108/ 14720701211234609

Mahmood, Z., Kouser, R., Ali, W., Ahmad, Z., \& Salman, T. (2018). Does corporate governance affect sustainability disclosure? A mixed methods study. Sustainability, 10(1), 207. https://doi.org/10.3390/su10010207

Mishchuk, H., Yurchyk, H., \& Bilan, Y. (2018). Shadow Incomes and Real Inequality Within the Framework of Leadership and Social Change. In Leadership for the Future Sustainable Development of Business and Education (pp. 89-101). Springer, Cham. https://doi.org/10.1007/978-3-319-74216-8_10

Mustapa, W. N. W., Al Mamun, A., \& Ibrahim, M. D. (2019). Evaluating the effectiveness of development initiatives on enterprise income, growth and assets in Peninsular Malaysia. Economics and Sociology, 12(1), 39-60. https://doi.org/10.14254/2071-789X.2019/12-1/2

Nafei, W. A., Khanfar, N. M., \& Kaifi, B. A. (2012). Leadership styles and organizational learning an empirical study on Saudi banks in Al-Taif Governorate Kingdom of Saudi Arabia. Journal of Management and Strategy, $3(1), 2$. https://doi.org/10.5430/jms.v3n1p2

Obeidat, B. Y., Abdallah, A. B., Aqqad, N. O., Akhoershiedah, A., \& Maqableh, M. (2017). The effect of intellectual capital on organizational performance: The mediating role of knowledge sharing. Communications and Network, 9(1), 1-27. https://doi.org/10.4236/cn.2017.91001

Oppen, C., \& Brugman, L. (2009). Organizational capabilities as the key to sustainable innovation. Journal World Review of Entrepreneurship, Management and Sustainable Development, 6, 18-31.

Pachura, A. (2015). Innovativeness of an enterprise in the context of technology globalisation. Polish Journal of Management Studies, 12 (1), 143-153.

Podolny, J., Khurana, R., \& Hill-Popper, M. (2005). How to put meaning back into leading. HBS Working Knowledge.

Salem, M. A., Shawtari, F., Shamsudin, M. F., \& Hussain, H. B. I. (2018). The consequences of integrating stakeholder engagement in sustainable development (environmental perspectives). Sustainable Development, 26(3), $255-268$. https://doi.org/10.1002/sd.1699

Sekaran, U., \& Bougie, R. (2016). Research methods for business: A skill building approach: John Wiley \& Sons.

Shpak, N., Satalkina, L., Sroka, W., \& Hittmar, S. (2017). The social direction of enterprises' innovation activity. Polish Journal of Management Studies, 16 (1), 187-201. https://doi.org/10.17512/pjms.2017.16.1.16

Shrivastava, P., \& Addas, A. (2014). The impact of corporate governance on sustainability performance. Journal of Sustainable Finance \& Investment, 4(1), 21-37. https://doi.org/10.1080/20430795.2014.887346 
Theodore, J. (2013). Absence of transformational leadership in Greek enterprises results in the inability of forming learning organizations. The International Business \& Economics Research Journal (Online), 12(6), 701. https://doi.org/10. 19030/iber.v12i6.7874

Tourish, D. (2014). Leadership, more or less? A processual, communication perspective on the role of agency in leadership theory. Leadership, 10(1), 79-98. https://doi.org/10.1177/1742715013509030

Ulrich, D., \& Smallwood, N. (2004). Capitalizing on capabilities. Harvard Business Review, 119-128.

Ussahawanitchakit, P. (2017). Management Control Systems and Firm Sustainability: Evidence from textile and apparel businesses in Thailand. Asian Academy of Management Journal, 22(2), 185-208. https://doi.org/10.21315/ aamj2017.22.2.7

Valickas, A., Raisiene, A. G., \& Arimaviciute, M. (2017). Leadership competences for the excellence of municipalities' strategic management. Journal of International Studies, 10(4), 131-142. https://doi.org/10.14254/2071-8330.2017 /10$4 / 10$

Wallach, E. J. (1983). Individuals and organizations: The cultural match. Training \& Development Journal.

Wang, F. J., Chich-Jen, S., \& Mei-Ling, T. (2010). Effect of leadership style on organizational performance as viewed from human resource management strategy. African Journal of Business Management, 4(18), 3924-3936.

Yahaya, R., \& Ebrahim, F. (2016). Leadership styles and organizational commitment: literature review. Journal of Management Development, 35(2), 190-216. https://doi.org/10.1108/JMD-01-2015-0004

Zainol, N. R., Al Mamun, A., Ahmad, G., \& Simpong, D. B. (2018). Human Capital and Entrepreneurial Competencies towards Performance of Informal Microenterprises in Kelantan, Malaysia. Economics and Sociology, 11(4), 31-50. https://doi.org/10.14254/2071-789X.2018/11-4/2

Zehir, C., \& Acar, A. Z. (2006). Organizational capabilities and its impacts on business performance. Paper presented at the The Proceedings of 2nd International Strategic Management Conference.

Zingales, L. (1998). Corporate Governance." C.E.P.R. Discussion Papers. CEPR Discussion Papers: 1806.

The article has been reviewed. Received in August 2019; accepted in February 2020. 